\title{
Sciendo
}

DOI: $10.2478 / \mathrm{aa}-2020-0005$

\section{The Shadow and the dual-identity avenger tradition in American popular fiction}

Jozef Pecina

Jozef Pecina is an Assistant Professor at the Department of British and American Studies at the Faculty of Arts, Comenius University in Bratislava. He received his PhD. in British and American Literature at the Faculty of Arts, Palacký University, Olomouc. He teaches American history and American literature. His main fields of interest are antebellum history, popular fiction, and comic books. He is the author of The Representation of War in Nineteenth-Century American Novels (2015), and he has published numerous articles on James Fenimore Cooper, antebellum sensational novels, superheroes and eye-gouging.

\begin{abstract}
:
A secret identity is one of the definitional characteristics of comic-book superheroes. However, American popular literature had been populated by characters with secret identities long before the first superhero comics appeared. The crime-fighting dual-identity vigilantes enjoyed their heyday in the 1930s and 1940s, during the golden era of pulps. Selling usually for 10 cents, pulp magazines were the best source of cheap thrills and heroics. In this era, dozens of costumed avengers appeared and the most popular was undoubtedly The Shadow. Between 1931 and 1949, Street and Smith published more than three hundred stories featuring The Shadow, most of them written by Walter B. Gibson. In the late 1930s, several of the pulp conventions, including costumed avengers, were adopted by the creators of the superhero comic books, and The Shadow served as a main inspiration for Bill Finger's and Bob Kane's Batman. The article discusses the evolution of crime-fighting pulp heroes with a particular emphasis on The Shadow as the most influential dual-identity avenger of the era.
\end{abstract}

Thanks to blockbuster films of the last two decades, millions of people around the entire planet have become familiar with names like Peter Parker, Bruce Wayne and Tony Stark. Nowadays, one does not need to be a hard-core comic book fan to instantly recognize these fictional characters and know that they have superhero secret identities. However, only a fraction of today's film audiences are aware of the fact that comic book superheroes have been saving the world since the end of the 1930s. Indeed, the fact that there were characters with dual identities battling evil and crime even before the advent of superheroes is probably 
known only among popular literature scholars. The aim of the present article is to trace the development of dual-identity avengers in American popular fiction with an emphasis on The Shadow, the best-known pulp character of the 1930s.

In the last two decades, numerous scholarly works dedicated to superheroes have appeared, among them Peter Coogan's Superhero: The Secret Origin of the Genre (2005), Chris Gavaler's On the Origin of Superheroes: From the Big Bang to Action Comics No. 1 (2015), and Jess Nevins' The Evolution of the Costumed Avenger (2017). The present article focuses on what Nevins calls "protosuperheroes" (2017, p. xiv), which are characters with the definitional characteristics of superheroes who were created before the appearance of Superman and his alter ego Clark Kent in 1938. Coogan distinguishes three types of protosuperheroes, namely the science-fiction superman (e.g., H. G. Wells' Invisible Man), the pulp übermensch (e.g., E. R. Burroughs' Tarzan of the Apes), and the dual-identity crime-fighting avenger-vigilante (2005, p. 126). By contrast, Nevins uses the much more simple term of "costumed avenger", which he defines as "any character who wears a recognizable and consistent costume while fighting crime or evil" (2017, p. 13).

Characters with secret identities have been present in American fiction since its very beginning. The best known is probably Harvey Birch, the protagonist of James Fenimore Cooper's first successful novel, The Spy. But Birch is a spy, not a vigilante. The first dualidentity vigilante as such appears in Robert Montgomery Bird's gory frontier gothic novel, Nick of the Woods or the Jibbenainosay (1837). However, there is a link between Bird's novel and Cooper's work since it was written as a reaction to Cooper's Leatherstocking Tales. Bird considered Cooper's pentalogy to be inaccurate in its depiction of Indians, and therefore his frontier is significantly different from the frontier of his predecessor. It is a much more violent place, and Bird completely rejects the idea of the noble savage. Bird's view thus opposes Cooper's racially inclusive image of the frontier.

Montgomery Bird's vigilante is Jibbenainosay, a mysterious being who roams the woods and wreaks havoc among the Kentucky Indians while never hurting a white settler. The Indians consider him to be invincible, "neither man nor beast, but a great ghost or devil that knife cannot harm nor bullet touch" (Bird, 1837, p. 50). He is described by those who caught a glimpse of him in the woods as "a great tall fellow with horns and a hairy head like a buffalo-bull" (Bird, 1837, p. 53). He maims his victims in a truly brutal manner, always leaving them with his trademark shape of a cross slashed into their chests, "two gashes wide and gory on the breast, traced by a sharp knife and a powerful hand, and, as it seemed, in the mere wantonness of a malice and lust of blood which even death could not satisfy" (Bird, 
1837, p. 71). Peter Rollins calls him a "one-man genocide squad" (2003, p. 277), and that is what he is: a ruthless war machine and by far the most violent and most racist vigilante of 19th-century American fiction.

Jibbenainosay's alter ego is Nathan Slaughter, a pacifist and reclusive Quaker. He is known to the settlers as a person who avoids bloodshed at all costs and would use his old rifle only to hunt game, being described as "the only man in all Kentucky that won't fight" (Bird, 1837, p. 65). True to his religious beliefs, Slaughter refuses to take up arms against the Indians, which earns him only ridicule and scorn. In terms of a dual identity, Nathan Slaughter is what Clark Kent is for Superman: an awkward and clumsy coward.

The transformations of dual-identity vigilantes are often explained by their origin stories. According to Hatfield, an origin story is "the bedrock account of the transformative events that set the protagonist apart from ordinary humanity" (2013, p. 3). Ten years before the events of the novel, Nathan Slaughter was a Pennsylvania frontiersman, living on a small farm with his mother, wife and five children. One day, a band of Shawnees led by Chief Wenonga descends upon the farm and massacres his entire family in front of his eyes before scalping him and leaving him for dead. However, Slaughter survives the butchery and moves down to Kentucky to track Wenonga down, exacting revenge on every Indian he comes across in the woods. In the final confrontation, he kills Wenonga in his own tepee, not as Jibbennainosay but as Nathan Slaughter:

And with that, leaping upon the astounded chief with rather the rancorous ferocity of a wolf than the enmity of a human being, and clutching him by the throat with one hand, while with the other he tore the iron tomahawk from his grasp, he bore him to the earth, clinging to him as he fell, and using the wrested weapon with such furious haste and skill, that before they had yet reached the ground, he had buried it in the Indian's brain. Another stroke, and another, he gave with the same murderous activity and force; "Ay, dog, thee dies at last! at last I have caught thee!" With these words, Nathan, leaving the shattered skull, dashed the tomahawk into the Indian's chest, snatched the scalping-knife from the belt, and with one grinding sweep of the blade, and one fierce jerk of his arm, the gray scalp-lock of the warrior was torn from the dishonoured head. (Bird, 1837, p. 206)

Although Michael Lopez calls him "Batman in buckskins" (quoted in Coogan, 2005, p. 150), there is a significant difference between the motivations of Batman and Bird's vigilante. Jibbenainosay seeks punishment and retribution rather than protection of the weak. While Batman commits acts of violence in order to protect Gotham's citizens from crime, Jibbenainosay kills Indians as an act of vengeance (Coogan, 2005, p. 151). Nevertheless, Bird 
successfully created a vigilante figure who has two well-developed identities and an origin story, and he fights evil while wearing a disguise (Nevins, 2017, 102).

Dual-identity avengers enjoyed their heyday in the 1930s and 1940s, during the golden era of pulps. As Hoppenstand states, in this era "dozens of pulp vigilante heroes laughed, whispered, blasted, battled and killed their way through the fictional 'mean streets' of Depression America" (1982, p. 143). Pulp magazines developed from dime novels, which were popular in the late 19th century and were the forerunners of paperback thrillers as well as comic books. The name is derived from the cheap, low-grade pulpwood paper on which they were printed. They were distinguished by mass production, affordability and a dependence on formula and genre. The authors of the stories published in pulps were never considered great writers; what mattered in the business was not quality but rather the ability to write quickly and provide fast-paced plots. Industry was more important than artistry (Server, 2002, pp. xi-xii). Selling usually for 10 cents, pulps offered every possible genre and every possible kind of hero. As Goulart claims, "the pulps sold cowboys, detectives, lumberjacks, spies, Royal Canadian Mounted Policemen, sandhogs, explorers, ape men, aviators, phantoms, robots, talking gorillas, boxers, G-men, doughboys, spacemen, Foreign Legionaries, knights, crusaders, reporters, Masked Marvels, ballplayers, doctors, playboys, pirates, kings, stuntmen, cops, commandos and magicians" (1972, p. 29). Hero pulps (or single-character pulps) appeared in the early 1930s and focused on the adventures and exploits of one particular protagonist. The concept of a recurring hero was not new; it had already been introduced by Beadle and Adams, a leading publisher of dime novels, in the company's highly popular Deadwood Dick series in the 1870s, which, interestingly, also featured a masked double-identity protagonist. According to Nevins, hero pulps were rarely as well written as other genres and never as critically accepted (2017, p. 164). However, thanks to protagonists such as The Shadow and Doc Savage, they are better remembered nowadays than other pulps. Moreover, it was this genre that had the most significant impact on the development of popular culture in decades to come.

Hoppenstand identifies four main detective archetypes: the classical detective, the police detective, the hard-boiled detective and the avenger detective. In the early years of the Depression, the classical detective held less relevance for mass audiences, and thus "a new archetype emerged in the popular press and radio to captivate the nation's fancy by effectively solving criminal problems with vigilante violence. This new detective ... catered to the societal desire for simplified solutions to complex problems" (1984b, p. 91). He adds that this new hero deals with radical social changes using radical methods. In classical detective 
fiction, the protagonist only rarely uses violence to apprehend criminals. Contrary to the classical detective archetype, the avenger detective is less skilled in detection and more skilled in violence, and he would always use his guns or fists to kill or hurt rather than apprehend the crook. Avenger detective stories usually include the total elimination of the criminal element from society. The emphasis is on physical strength rather than mental capability and on action rather than investigation. Another major difference is that the avenger detective is superhuman. He can shoot straighter, hide deeper and deliver his punches with greater strength (Hoppenstand, 1982, p. 4).

In July 1930 a publisher called Street and Smith decided to promote its Detective Story Magazine on radio, and a programme named Detective Story Hour was launched. It was introduced by a sinister voice that originally had no name, but eventually, the scriptwriters dubbed the voice "The Shadow". The voice became extremely popular among listeners and soon Street and Smith "was trying to figure out how to exploit The Shadow in print as well" (Server, 2002, p. 116). The company hired Walter Gibson who, according to the Encyclopedia of Pulp Fiction Writers, was "a professional magician - the president of the Philadelphia chapter of the Society of American Magicians by 1926 - and magicologist. He was, as well, a reporter, a composer of crossword puzzles, the ghostwriter for the world-famous magician Howard Thurston and the even more famous Harry Houdini, and the author of numerous nonfiction books on the subject most dear to him, including After Dinner Tricks, Popular Card Tricks, and The Book of Secrets, Miracles Ancient and Modern" (2002, p. 115). By the time he began writing The Shadow stories, Gibson had already authored twenty-seven books and more than two hundred articles and stories (including detective stories for various true crime magazines).

Street and Smith was initially very cautious. Gibson remembered that he had been asked to write one story, and if the first issue proved successful in terms of sales, he would be contracted to add three more. To save money, the cover of the first issue was recycled from a 1919 magazine since it was "the only piece of art anyone could find with a shadow on it" (Goulart, 1972, p. 45). It featured a sinister Oriental character. Since Gibson had no such character in the chapters he had already written, he had to add a scene in Manhattan's Chinatown, naming the chapter "The Tea Shop of Wang Foo" (Shimeld, 2003).

The first Shadow story, The Living Shadow, was published in April 1931 and was an immediate success. The magazine soon changed from quarterly to monthly and in no time, Gibson found himself writing a Shadow story every two weeks. Using the pseudonym Maxwell Grant, Gibson wrote 283 novel-length stories between 1931 and 1949. According to 
Sampson, it was the Great Depression that made The Shadow one of the most famous fictional characters of its era: "The Depression was just getting into full collapse. What was needed was some sort of figure acting within the popular mythology to strike out against all the menaces, from gangster domination to government corruption, that everybody perceived were floating around, destroying the society, ruining the economy and otherwise causing havoc" (quoted in Shimeld, 2003). Gavaler calls The Shadow "the biggest superhero of the Depression, an industry transforming mystery man indistinguishable from the shadow world he polices" (Gavaler, 2015).

The Shadow is a creature of the night. When he appears for the first time in The Living Shadow to save a man who is trying to commit suicide, he is described as "a tall, black cloaked figure that might have represented death itself" (The Living Shadow, 1931). A black cloak and black slouch hat make up his default costume, but The Shadow is a master of disguise and adopts a number of false identities. It is his ability to glide noiselessly and melt into the night where his moniker originated. When he speaks, it is always in a whispering voice; but what echoes in the dark alleys and basements the most is his trademark laugh. Described variously as "a strange, unaccountable laugh; a laugh that would chill the heart of a man who had never known fear" (The Living Shadow, 1931) or "a long, raucous laugh; a laugh that taunted; a laugh that meant much more than words" (The Shadow Laughs, 1931), it always seems to make even the most hardened crooks stare in alarm and strikes terror into their villainous hearts.

The Shadow's real identity is his greatest secret. Even his closest associates know very little about who he really is. There are no scenes that would show him before or after slipping into disguise. It looks like even Gibson himself was initially not sure who The Shadow really was. In the first two novels, the reader is led to believe that The Shadow is a millionaire named Lamont Cranston. Cranston has a driver and a trustworthy butler and lives in a lavish mansion which is equipped with a state-of-the-art wireless radio set. Bruce Wayne immediately comes to a comic book fan's mind. However, there is a bizarre and confusing chapter named "Lamont Cranston Talks to Himself" in The Shadow Laughs (1931), the third novel of the series, where the millionaire wakes up in the middle of the night to see a figure that at first looks like a huge shadow but turns out to be an exact double of Cranston, even having an identical voice. The stranger is The Shadow disguised as Lamont Cranston who, using threats, instructs the real Cranston to leave the country so that The Shadow can virtually steal Cranston's identity and use his vast resources in order to fight crime. In novels to come, The Shadow poses as Cranston while the real Cranston is abroad. Only in The Shadow novel 
No. 131, The Shadow Unmasks (1937), is the meaning of that chapter together with The Shadow's origin story and real identity revealed. His real identity is that of Kent Allard, a World War One ace and a famous aviator. But aviation does not provide Allard with enough adrenaline and satisfaction, and therefore he decides to fight crime: "I saw such a necessity in a field that others had neglected. Crime was becoming rampant in America and elsewhere. Underworlds were organized, with their own hidden battle lines. Only a lone foe could pierce that cordon; once inside, he would have to move by stealth, and strike with power and suddenness. I chose that mission" (The Shadow Unmasks, 1937). Contrary to Jibbenainosay, there is no hatred and no traumatic experience from the past that would put Allard on the path of vigilantism. The Shadow is a pro-social and selfless individual who decides to act as the champion of the oppressed.

The plots of The Shadow novels were fast-paced and formulaic, and they often included twists at the end. The Shadow's opponents usually involved various criminal masterminds, smugglers and jewel thieves, and a plethora of generic Depression-era thugs and crooks. Interestingly, in The Red Menace (1931), order is threatened by a ring of Soviet communists, led by the mysterious Red Envoy, who are seeking to steal plans for "aerial torpedoes" that would give their country a military advantage. The story also includes a bizarre scene with two masked figures, when The Shadow, wearing his black cloak and black slouch hat confronts the Red Envoy who is wearing a crimson mask and red gloves.

The world of Gibson's pulp novels was incredibly masculine. In some instances, particularly in the early stories, it looks like American cities were populated by men only, since several stories are written without a single female character. Sometimes, female characters appear in the role of secretaries, but more often they were there just to be rescued. Only later did Gibson add Margo Lane, a female sidekick who often saves The Shadow. There was neither sex nor nudity in Gibson's The Shadow stories. As Shimeld observes, the stories were "long on violence and short on sex" (Shimeld, 2003). One notable exception is The Smugglers of Death (1939) where a character named Myrna Elvin swims naked ashore from an island off the coast of Connecticut. She expects to find spare clothes in a cottage she owns, but the cottage is occupied by crooks, "cutting Myrna off from a goal that had become tremendously important, considering her unclad state" (The Smugglers of Death, 1939). She crawls into a cellar, where she finds The Shadow lying unconscious on the floor. She eventually ends up donning The Shadow's black cloak and slouch hat only to lose them in a fight with the crooks. The prudishness typical for Hollywood movies, where all kinds of violence was accepted but sex was a taboo, was already present in pulp magazines. Regarding 
violence, Gibson remarked that "World War I had had a violent impact on audiences, and we were starting to get a foretaste of the world we have now, with crime and violence everywhere. I wish I could have left out some of it, but that's what the public liked" (Shimeld, 2003). However, the depictions of violence are never explicit. Punches are exchanged, and gangsters are dropped by The Shadow's trademark .45 automatics by the dozen, but there is seldom a mention of blood or other gory details.

The dual-identity avenger prototype from pulp magazines culminated in the comicbook superheroes that came into existence at the end of the 1930s. Several of the pulp conventions were adopted by the creators of the earliest superhero comic books. Together with mission and superpowers, a secret identity became one of the definitional characteristics of these newly minted superheroes. A direct link between The Shadow and Batman has been admitted by Bill Kane, Batman's creator: “I suppose both The Shadow's cloaked costume and double identity role, as well as the extraordinary acrobatics of Douglas Fairbanks Sr., did more to my subconscious to create the character and personality of Batman than any other factors...My first script was a take-off of a Shadow story. I patterned my style of writing after The Shadow. It was completely pulp style" (Murray, 2009, p. 163). Despite the fact that Gibson saw Batman as a "clowned-up version" of The Shadow (Shimeld, 2003), in 1981, fifty years after he wrote his first Shadow story and forty years after Finger and Kane had created Batman, Gibson wrote a story for Detective Comics \#500, an anniversary edition of the title where the Caped Crusader appeared for the first time. It was called "The Batman Encounters Gray Face" and it was to be the last piece of fiction Gibson ever wrote. He passed away four years later aged 87 , leaving a legacy of nearly three hundred novels that featured the most popular avenger of the golden era of pulps.

\section{Works cited:}

Bird, R. M. 1837. Nick of the Woods or The Jibennainosay. A Tale of Kentucky. Philadelphia: Carey, Lea \& Blanchard.

Coogan, P. 2005. Superhero. The Secret Origin of a Genre. Austin: MonkeyBrain Books. Gavaler, Ch. 2015. On the Origin of Superheroes. From the Big Bang to Action Comics No. 1. Iowa City: University of Iowa Press.

Goulart, R. 1972. Cheap Thrills; An Informal History of the Pulp Magazines. New Rochelle: Arlington House.

Grant, M. 1931. The Living Shadow. New York: Street and Smith. Kindle.

Grant, M. 1931. The Shadow Laughs. New York: Street and Smith. Kindle.

Grant, M. 1931. The Red Menace. New York: Street and Smith. Kindle.

Grant, M. 1937. The Shadow Unmasks. New York: Street and Smith. Kindle.

Grant, M. 1931. The Smugglers of Death. New York: Street and Smith. Kindle. 
Hatfield, Ch. 2013. 'Historical Considerations'. In: Hatfield, Ch. et al. (eds.). The Superhero Reader. Jackson: University Press of Mississippi, pp. 3-7.

Hoppenstand, G. 1982. 'Introduction: The Missing Detective'. In: Hoppenstand, G. (ed.). The Dime Novel Detective. Bowling Green: Bowling Green University Popular Press, pp. 3-4.

Hoppenstand, G. 1984a. 'Pulp Vigilante Heroes, the Moral Majority and the Apocalypse'. In: Browne, R. and M. V. Fishwick (eds.). The Hero in Transition. Bowling Green: Bowling Green University Popular Press, pp. 141-150.

Hoppenstand, G. 1984b. 'Taboo and Detective Fiction'. In: Browne, R. (ed.). Taboos and Tabooism in Culture. Bowling Green: Bowling Green University Popular Press, pp. 83-96.

Murray, W. 2009. 'Two Dark Knights. The Batman and The Shadow'. In: Eury, M. and M. Kronenberg (eds.). The Batcave Companion. Raleigh: TwoMorrows Publishing, pp. 162-165. Nevins, J. 2017. The Evolution of the Costumed Avenger: The 4,000-Year History of the Superhero. Santa Barbara: Praeger.

Rollins, P. 2003. The Columbia Companion to American History on Film. New York: Columbia University Press.

Server, L. 2002. 'Introduction'. In: Server, L. Encyclopedia of Pulp Fiction Writers. New York: Facts on File, pp. xi-xvi.

Server, L. 2002. 'Gibson, Walter'. In: Server, L. Encyclopedia of Pulp Fiction Writers. New York: Facts on File, pp. 115-119.

Shimeld, T. 2003. Walter B. Gibson and The Shadow. Jefferson: McFarland \& Company. Kindle.

Jozef Pecina

Filozofická fakulta Univerzity Komenského

Gondova 2

81499 Bratislava

jozef.pecina@uniba.sk 